\title{
PENGARUH KUALITAS PRODUK DAN HARGA TERHADAP KEPUTUSAN PEMBELIAN MELALUI MINAT BELI PRODUK COSMETICS JAFRA PADA PT. JAFRA COSMETICS INDONESIA
}

\author{
Bella Hartati \\ Magister Manajemen, Universitas Jambi \\ e-mail : Bellahartati0@gmail.com
}

\begin{abstract}
Abstrak
Penelitian ini bertujuan menganalisis pengaruh kualitas produk dan harga terhadap keputusan pembelian produk kosmetik JAFRA melalui minat beli dan menganalisis variabel yang berpengaruh paling dominan terhadap keputusan pembelian. Populasi dalam penelitian ini adalah konsumen yang menggunakan atau pernah menggunakan kosmetik JAFRA, Teknik pengambilan sampel dalam penelitian ini menggunakan purposive sampling dengan mengambil 97 responden berdasarkan kriteria. Metode pengumpulan data menggunakan studi lapangan dalam bentuk kuesioner oline. Alat analisis data dalam penelitian ini menggunakan uji validitas, uji reabilitas, uji asumsi klasik dan patrial least square versi 3,2 for windows. Hasil penelitian menunjukkan bahwa kualitas produk dikategorikan baik, harga tergolong tinggi, minat beli setuju, dan keputusan pembelian sangat setuju memiliki produk kosmetik JAFRA dan variabel yang paling dominan berpengaruh terhadap keputusan pembelian yaitu variabel minat beli.
\end{abstract}

Keyword : Kualitas Produk, Harga, Minat Beli, Keputusan Pembelian

\begin{abstract}
Abstact
This study aims to analyze the effect of product quality and price on purchasing decisions for JAFRA cosmetic products through purchase intention and to analyze the variables that have the most dominant influence on purchasing decisions. The population in this study are consumers who use or have used JAFRA cosmetics. The sampling technique in this study used purposive sampling by taking 97 respondents based on criteria. Data collection method used a field study in the form of an online questionnaire. Data analysis tools in this study used validity test, reliability test, classical assumption test and patrial least square version 3,2 for windows. The results showed that the product quality was categorized as good, the price was high, the purchase intention agreed, and the purchase decision strongly agreed to have JAFRA cosmetic products and the most dominant variable that had an effect on purchasing decisions was the purchase intention variable.
\end{abstract}

Keyword : Product Quality, Price, Buying Interest, Purchase Decision

\section{PENDAhULUAN}

Perkembangan bisnis global saat ini sangat mengalami kemajuan yang sangat pesat, salah satunya ditandai dengan munculnya perusahaan - perusahaan yang membuat produk yang sama. Sehingga pengusaha dituntut untuk memenuhi kebutuhan konsumen. Untuk mendapatkan pangsa pasar, perusahaan harus melakukan banyak strategi sempurna untuk membangun keunggulan kompetitif, alhasil barang yang ditawarkannya dapat terjual dengan baik. Setiap perusahaan perlu melakukan ini untuk mempertahankan dan memenuhi kebutuhan konsumen yang sudah ada, salah satunya pada industri kosmetik.

Salah satunya yaitu perusahaan yang bergerak di bidang kosmetik yaitu JAFRA milik Jan dan Frank Day. JAFRA Cosmetics Indonesia didirikan di Malibu, California 


\section{Jurnal Manajemen Terapan dan Keuangan (Mankeu) Vol. 10 No. 01, April 2021 P-ISSN: 2252-8636, E-ISSN: 2685-9424}

pada tahun 1956 oleh distributornya PT JAFRA Cosmetics Indonesia melalui sistem bisnis multi-level marketing. Perusahaan JAFRA dituntut untuk memahami perilaku konsumen dalam mengambil keputusan pembelian produk kosmetik melalui minat beli dan bagaimana menghadapi persaingan dengan perusahaan sejenis yang lebih awal menguasai pasar. Untuk menarik konsumen agar menggunakan produk yang disediakan, kualitas produk sangat penting, karena pada dasarnya setiap orang yang ingin membeli suatu produk atau menggunakan produk jasa ingin mendapatkan produk yang berkualitas baik yang mereka beli. Selain kualitas produk, harga juga berpengaruh dalam keputusan pembelian melalui minat beli konsumen. Penetapan harga yang tepat akan mendapatkan perhatian minat beli dari konsumen. Jika harga yang ditetapkan oleh perusahaan tepat dan sesuai dengan daya beli maka konsumen akan memilih produk/jasa tersebut (Estu Mahanani, 2018). Harga sendiri telah membangkitkan banyak kesadaran di mata konsumen. Biasanya penilaian mereka mengasumsikan jika suatu produk mahal maka harganya akan lebih tinggi dibandingkan dengan produk sejenis, sebaliknya jika harganya lebih rendah dari produk sejenis maka akan terasa kualitasnya rendah.

Berdasarkan dari bahasan tersebut di atas dapat dikatakan bahwa kualitas produk dan harga merupakan faktor penting dalam mempengaruhi keputusan pembelian melalui minat beli konsumen. Karena seorang konsumen yang rasional akan memilih produk dengan mutu yang baik, harga yang terjangkau dan mudah didapat. Mutu produk yang diinginkan oleh konsumen menyangkut manfaatnya bagi pemenuhan kebutuhan dan keamanannya bagi diri konsumen. Pada penelitian yang dilakukan oleh Budiyono, Bernard NM (2004) menunjukkan bahwa kualitas produk merupakan salah satu syarat untuk mempengaruhi minat beli. Ketika konsumen membeli produk, mereka tidak hanya harus mempertimbangkan kualitasnya, tetapi juga kewajaran harga mereka, Sweeney et al. (2001). Harga merupakan salah satu penentu pemilihan produk yang mempengaruhi minat beli. Dorongan konsumen yang ingin tampil lebih baik dari orang lain dapat membuat konsumen dalam melakukan pembelian. Minat beli merupakan pernyataan mental dari konsumen yang menggambarkan rencana pembelian produk dengan merek tertentu (Adriansyah \& Aryanto, 2012).

\section{Rumusan Masalah}

Berdasarkan uraian latar belakang yang telah diuraikan sebelumnya, maka permasalahan yang diajukan dalam penelitian ini adalah :

1. Bagaimana pengaruh kualitas produk, harga terhadap keputusan pembelian produk kosmetik JAFRA melalui minat beli ?

2. Variabel apa yang paling berpengaruh terhadap keputusan pembelian produk kosmetik JAFRA ?

\section{Tujuan Penelitian}

Berdasarkan uraian rumusan masalah diatas, maka tujuan dari penelitian ini adalah :

1. Untuk menganalisis pengaruh kualitas produk dan harga terhadap keputusan pembelian produk kosmetik JAFRA melalui minat beli.

2. Untuk menganalisis variabel yang berpengaruh paling dominan terhadap keputusan pembelian.

\section{KAJIAN PUSTAKA}

\section{Manajemen}

Manajemen adalah fungsi untuk mencapai sesuatu melalui kegiatan orang lain dan mengawasi usaha-usaha individu untuk mencapai suatu kegiatan orang lain dan 
mengawasi usaha-usaha individu untuk mencapai tujuan bersama (Firmansyah \& Mahardika, 2018).

\section{Pemasaran}

Menurut American Marketing Association pemasaran adalah suatu fungsi organisasi dan serangkaian proses untuk menciptakan, mengkomunikasikan dan memberikan nilai kepada pelanggan untuk mengelola hubungan pelanggan dengan cara yang menguntungkan organisasi dan pemangku kepentingannya (Kotler \& Keller, 2016).

\section{Kosmetik}

Definisi kosmetik dalam Peraturan Menteri Kesehatan RI No. 445/Menkes/Permenkes/1998 adalah sebagai berikut : "Kosmetik adalah sediaan atau paduan bahan yang siap untuk digunakan pada bagian luar badan (epidermis, rambut, kuku, bibir, dan organ kelamin bagian luar), gigi, dan rongga mulut, untuk membersihkan, menambah daya tarik, mengubah penampakan, melindungi supaya tetap dalam keadaan baik, memperbaiki bau badan tetapi tidak dimaksudkan untuk mengobati atau menyembuhkan suatu penyakit" (BPOM, 2013).

\section{Kualitas Produk}

Kualitas merupakan syarat agar suatu nilai dari produk memungkinkan untuk bisa memuaskan pelanggan sesuai harapan (Tjiptono \& Chandra, 2012).

\section{Harga}

Dalam pemasaran pada umumnya berkaitan langsung dengan masalah harga suatu produk. Apakah harga sudah sesuai dengan kualitas produk, berapakah harga yang sesuai jika penentuan atau penetapan harga tidak sesuai dengan kondisi produk, tentu saja akan menjadi masalah bagi pemasar. Menurut Kotler harga adalah sejumlah uang yang di bebankan pada suatu produk tertentu (Sunyoto, 2014).

\section{Minat beli}

Kotler dan Keller (2003) meyakini bahwa minat beli konsumen adalah perilaku konsumen, yaitu konsumen membeli atau memilih suatu produk berdasarkan pengalaman mereka dalam memilih, menggunakan, mengonsumsi atau bahkan menginginkan suatu produk. Untuk menarik atau menumbuhkan minat konsumen dalam membeli, pemasar harus terlebih dahulu memahami perilaku konsumen selama pembelian. Karena yang harus dilakukan konsumen setelah dipengaruhi oleh pemasar adalah bagaimana mereka memutuskan untuk membeli atau menolak produk yang ditawarkan (Rizki, 2018).

\section{Keputusan pembelian}

Menurut (Kotler \& Keller, 2016), proses keputusan pembelian terdiri dari lima tahap yang dilakukan oleh seorang konsumen sebelum sampai pada keputusan pembelian dan selanjutnya pasca pembelian. Keputusan pembelian yang dilakukan oleh konsumen dapat terjadi apabila kosumen sudah mendapatkan pelayanan dari pemberian jasa dan setelah itu konsumen merasakan adanya kepuasan dan ketidakpuasan, maka dari itu konsep-konsep keputusan pembelian tidak lepas dari konsep kepuasan pelanggan.

\section{METODE PENELITIAN Populasi dan Sampel}

Populasi dalam penelitian ini yaitu konsumen yang menggunakan atau pernah menggunakan kosmetik JAFRA yaitu perempuan yang berusia $17-47$ tahun. Untuk pengambilan sampel responden menggunakan purposive sampling, yang mana dalam 
pengambilan sampel dilakukan atas dasar tujuan atau pertimbangan tertentu. Dan sampel dalam penelitian ini sebanyak 97 responden.

\section{Jenis Penelitian Dan Teknik Pengumpulan Data}

Penelitian eksplanasi ini bersifat menerangkan dan bertujuan untuk menjelaskan hubungan antar dua variabel atau lebih. Dalam penelitian ini variabel yang mempengaruhi adalah kualitas produk dan harga, variabel yang dipengaruhi adalah keputusan pembelian, sedangkan variabel intervening adalah minat beli. Jenis data yang digunakan dalam penelitian ini adalah data primer.

\section{Teknik Pengolahan dan Analisis Data}

Pengolahan dan analisis data pada penelitian ini menggunakan software SmartPLS versi 3.2 for windows. Metode analisis yang digunakan adalah metode analisis deskriptif dan patrial least square dengan analisis data statistik deskriptif yang digunakan yaitu uji validitas, uji reliabilitas, uji asumsi klasik.

\section{HASIL DAN PEMBAHASAN :}

\section{Uji Validitas dan Realibilitas}

\begin{tabular}{|l|l|l|l|}
\hline No & \multicolumn{1}{|c|}{ Variabel } & \multicolumn{1}{c|}{ Cronbach's Alpha $>0.6$} & \multicolumn{1}{c|}{ Validitas } \\
\hline 1 & Kualitas Produk & 0,983 (Reliabel) & $>0.05$ (Valid) \\
\hline 2 & Harga & 0,948 (Reliabel) & $>0.05$ (Valid) \\
\hline 3 & Minat Beli & 0,977 (Reliabel) & $>0.05$ (Valid) \\
\hline 4 & Keputusan Pembelian & 0,974 (Reliabel) & $>0.05$ (Valid) \\
\hline
\end{tabular}

Sumber : Hasil data yang diolah

\section{Uji Asumsi Klasik}

\section{Uji normalitas}

Uji normalitas adalah untuk melihat apakah nilai residual terdistribusi normal atau tidak.

Model regresi yang baik adalah memiliki nilai residual yang terdistribusi normal (Duli, 2019).

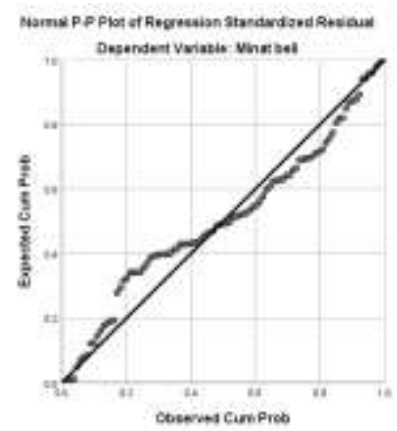

Grafik diatas menunjukkan bahwa grafik normal P-P of regression standartdized residual menggambarkan penyebaran ada disekitar garis diagonal dan penyebarannya mengikuti arah diagonal grafik tersebut, maka model regresi yang digunakan dalam penelitian ini memenuhi asumsi normalitas.

\section{Uji heteroskedastisitas}

Uji heteroskedastisitas adalah untuk melihat apakah terdapat ketidaksamaan varians dari residual satu pengamatan ke pengamatan lain (Duli, 2019). 


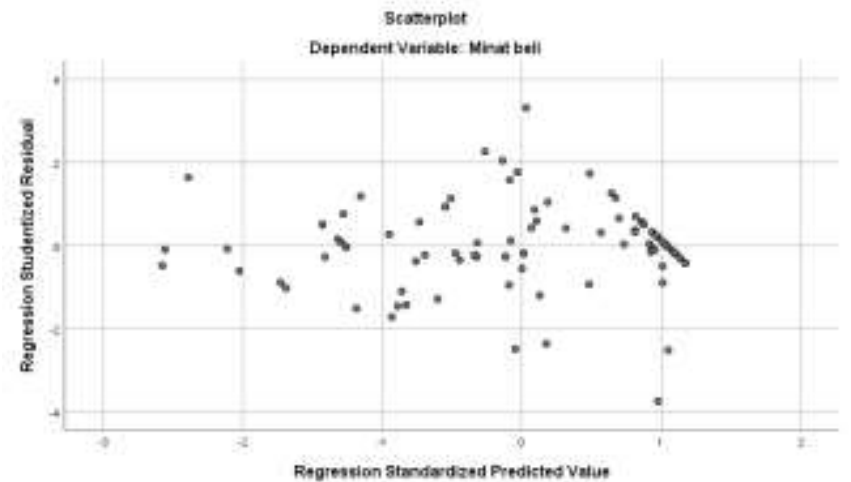

Grafik diatas adalah grafik Scarrerplot yang ditampilkan untuk uji heteroskedastisitas dapat dilihat bahwa titik - titik data tidak membentuk pola tertentu dan data menyebar diatas dan dibawah angka 0 pada sumbu Y. Maka dari itu dapat disimpulkan tidak terjadi gangguan uji heteroskedastisitas artinya model regresi ini sudah baik.

\section{Uji multikolonearitas}

Uji multikolonearitas bertujuan untuk melihat ada atau tidaknya korelasi yang tertinggi antara variabel-variabel bebas dalam suatu model regresi (Duli, 2019).

\begin{tabular}{|c|c|c|c|c|c|c|c|c|}
\hline \multirow[b]{3}{*}{ Model } & \multicolumn{8}{|c|}{ Coefficients $^{\mathrm{a}}$} \\
\hline & & \multicolumn{2}{|c|}{ Unstandardized Coefficients } & \multirow{2}{*}{$\begin{array}{c}\text { Standardized } \\
\text { Coefficients } \\
\text { Beta }\end{array}$} & \multirow[b]{2}{*}{$\mathrm{t}$} & \multirow[b]{2}{*}{ Sig. } & \multicolumn{2}{|c|}{ Collinearity Statistics } \\
\hline & & B & Std. Error & & & & Tolerance & VIF \\
\hline 1 & (Constant) & -2.182 & 1.468 & & -1.486 & .141 & & \\
\hline & Kualitas produk & .010 & .049 & .017 & .195 & .846 & .123 & 8.115 \\
\hline & Harga & .402 & .116 & .362 & 3.453 & .001 & .089 & 11.185 \\
\hline & Keputusan pembelian & .493 & .089 & .588 & 5.544 & .000 & .087 & 11.464 \\
\hline
\end{tabular}

Berdasarkan hasil diatas dapat dilihat pada output coefficients model, dikatakan bahwa nilai tolerance variabel kualitas produk $\left(\mathrm{X}_{1}\right) 0,123>0,10$, harga $\left(\mathrm{X}_{2}\right) 0,89>0,10$ dan keputusan pembelian (Y) 0,87>0,10. Sementara itu, nilai VIF variabel kualitas produk $\left(\mathrm{X}_{1}\right)$, harga $\left(\mathrm{X}_{2}\right)$ dan keputusan pembelian $(\mathrm{Y})<10$. Sehingga dapat diartikan semua data variabel terbebas dari multikolinearitas karena memiliki tolerance diatas 0,10 dan variabel kualitas produk $\left(\mathrm{X}_{1}\right)$ VIF dibawah 10 terbebas dari multikolinearitas sedangkan untuk harga $\left(\mathrm{X}_{2}\right)$ dan keputusan pembelian $(\mathrm{Y})$ terjadi multikolinearitas VIF diatas 10 .

\section{Patrial Least Square}

Dalam penelitian ini, metode analisis patrial least square pad model structure equation modeling (SEM). Analisis data dilakukan dengan bantuan software smart PLS 3.0 (Narimawati et al., 2020). Berikut hasil analisis yang dilakukan dalam Patrial Least Square: 


\section{Inner model}

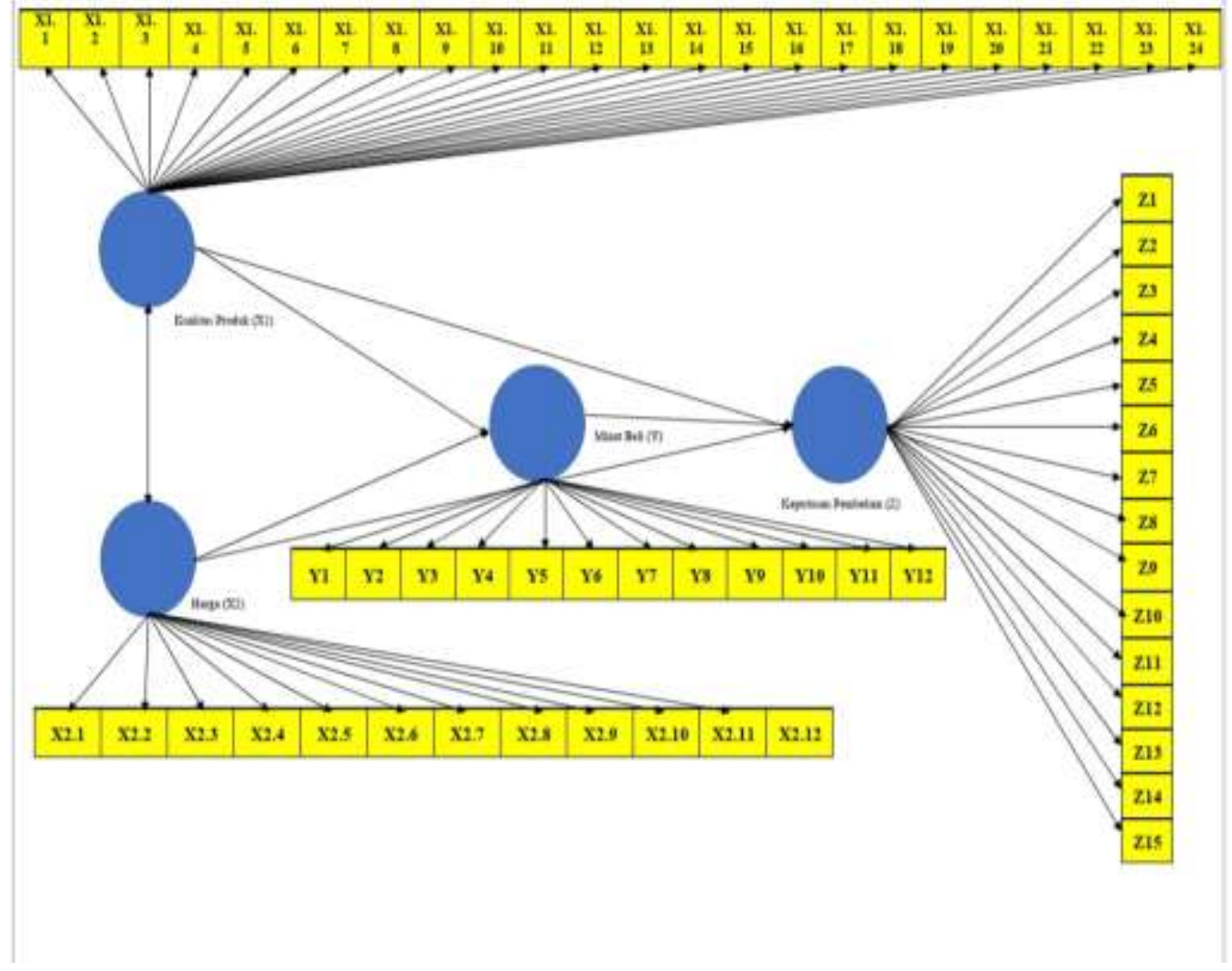

Berdasarkan gambar inner model terlihat adanya hubungan indikator dengan variabel latennya dan hubungan antar variabel laten. Variabel kualitas produk diukur menggunakan 24 indikator $\left(\mathrm{X}_{1.1}-\mathrm{X}_{1.24}\right)$, variabel harga diukur menggunakan 12 indikator $\left(\mathrm{X}_{2.1}-\mathrm{X}_{2.12}\right)$, variabel minat beli diukur menggunakan 12 indikator $\left(\mathrm{Y}_{1}-\mathrm{Y}_{12}\right)$, dan variabel keputusan pembelian diukur menggunakan 15 indkator $\left(Z_{1}-Z_{15}\right)$.

\section{Outer model}

Outer model menjelaskan hubungan antar indikator dengan variabel latennya masingmasing, sedangkan inner model menjelaskan antar variabel latennya. Dari gambar inner model terlihat jelas hubungan antara indikator dengan variabel latennya dan hubungan antar variabel laten. Sementara itu, variabel minat beli merupakan variabel intervening yang menghubungkan pengaruh kualitas produk dan harga terhadap keputusan pembelian.

\section{Mengkontruksi diagram jalur}

Diagram jalur adalah alat untuk melukiskan secara grafis, struktur hubungan kausalitas antara variabel independen, dependen, dan intervening. Berdasarkan gambar tersebut maka diagram jalur dapat digambarkan sebagai berikut : 


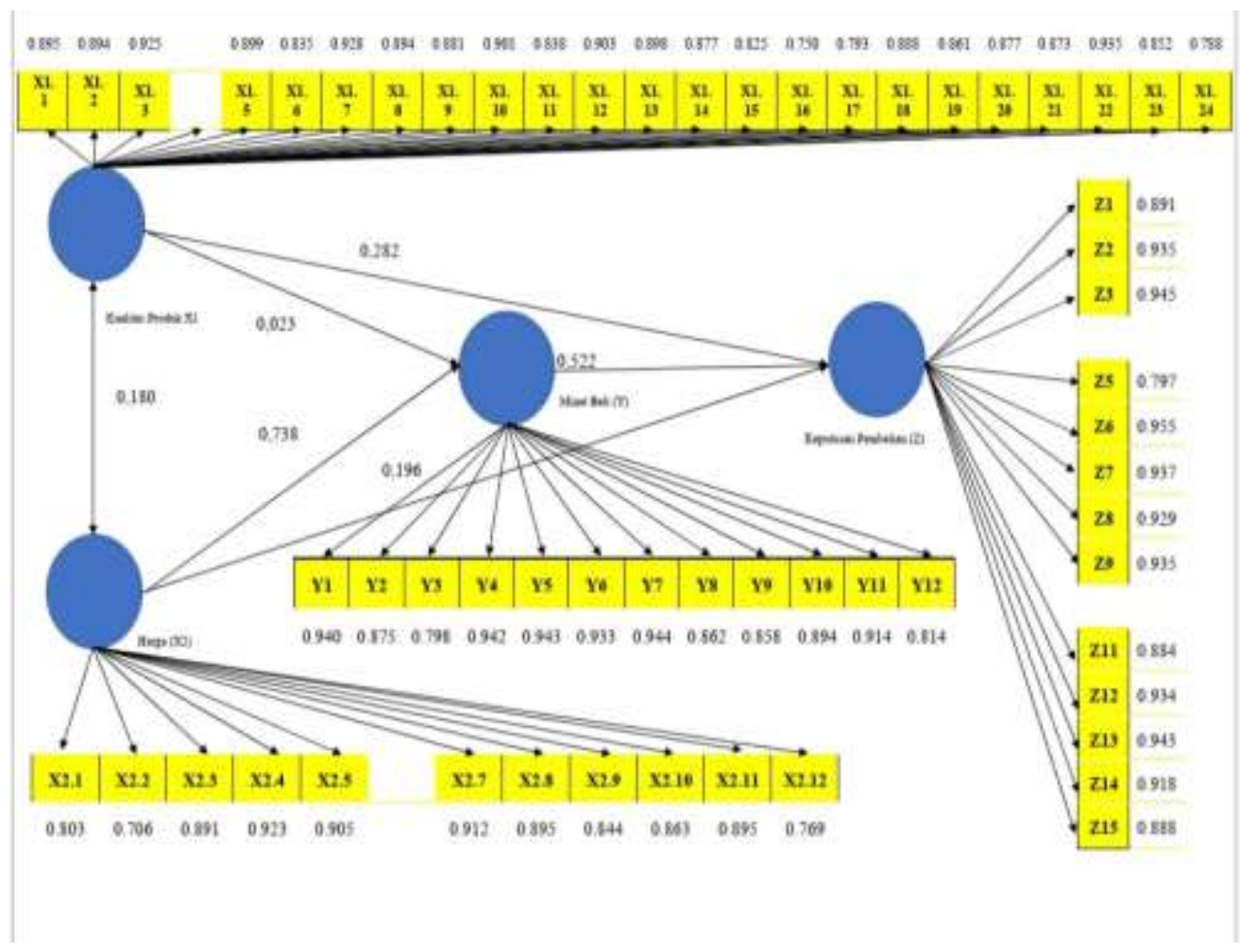

Konversi diagram jalur kepersamaan

\section{Evaluasi outer model}

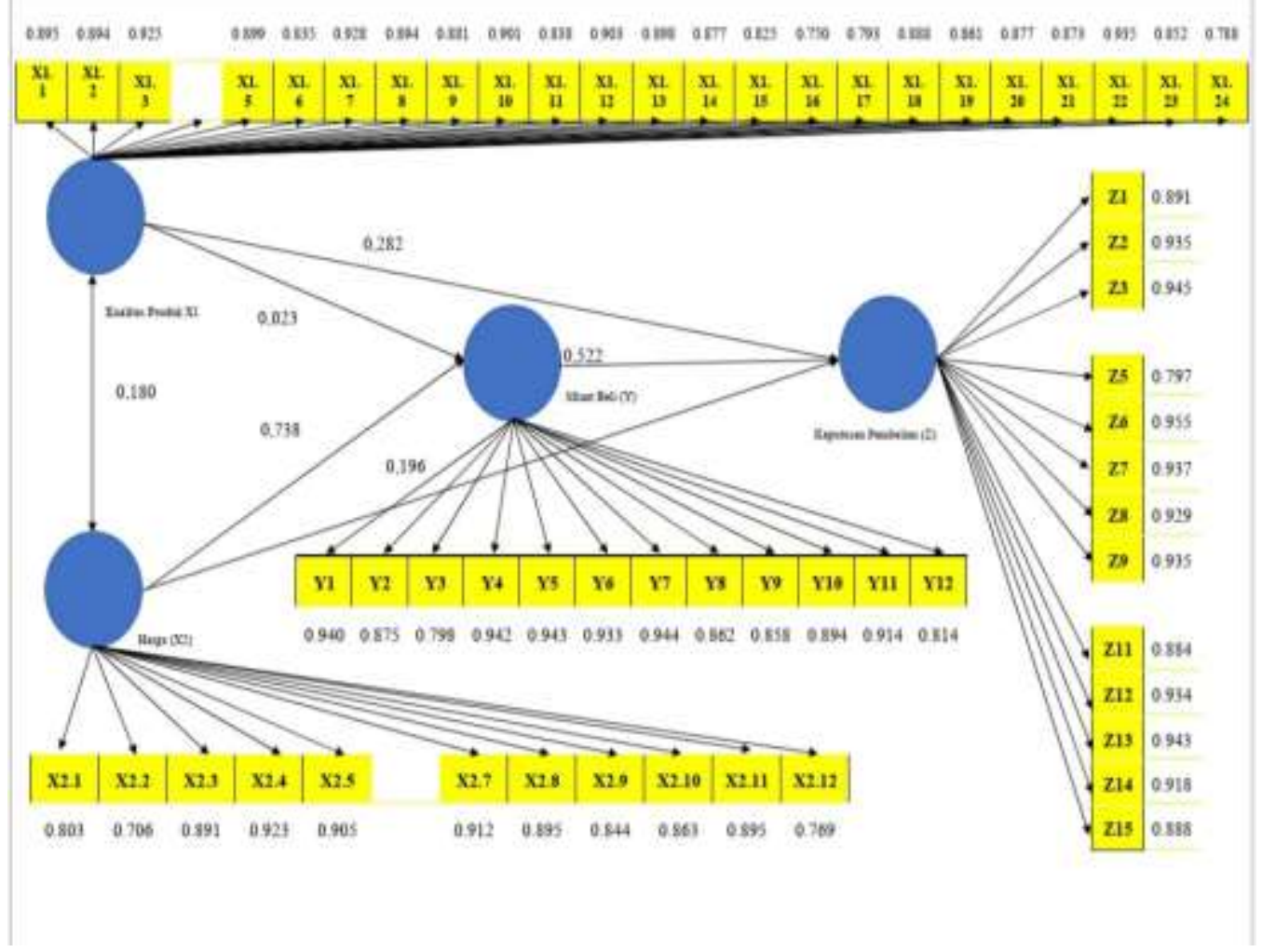


Berdasarkan gambar evaluasi outer model diketahui bahwa semua indikator memiliki hubungan positif terhadap masing-masing variabel laten loading factor untuk setiap indikator lebih besar dari 0,5 dan dikatakan cukup tinggi. Hasil tersebut menunjukkan bahwa penggunaan masing masing indikator tersebut mampu mengukur variabel laten secara tepat.

\section{Evaluasi Inner model}

Evaluasi inner model digunakan untuk menspesifikasi hubungan antar variabel laten yang satu dengan variabel laten lainnya dengan tingkat signifikan 10\%. Berdasarkan gambar evaluasi outer model dapat ketahui bahwa hubungan antara variabel kualitas produk, harga, minat beli dan keputusan pembelian memiliki nilai yang tinggi dan signifikan.

\section{Estimasi}

\begin{tabular}{|l|c|c|c|}
\hline & T Statistics & $\begin{array}{c}\text { P } \\
\text { Values }\end{array}$ & Hasil \\
\hline $\begin{array}{l}\text { Kualitas produk => minat } \\
\text { beli }\end{array}$ & 2,403 & 0,017 & Siginifikan \\
\hline $\begin{array}{l}\text { Kualitas produk } \\
\text { keputusan pembelian }\end{array}$ & 3,808 & 0,000 & Siginifikan \\
\hline Harga => minat beli & 8,147 & 0,000 & Siginifikan \\
\hline $\begin{array}{l}\text { Harga keputusan } \\
\text { pembelian }\end{array}$ & 1,654 & 0,094 & Tidak signifikan \\
\hline $\begin{array}{l}\text { Minat beli => keputusan } \\
\text { pembelian }\end{array}$ & 6,096 & 0,000 & Siginifikan \\
\hline $\begin{array}{l}\text { Kualitas produk => harga => } \\
\text { keputusan pembelian }\end{array}$ & 1,662 & 0,097 & Tidak signifikan \\
\hline $\begin{array}{l}\text { Kualitas produk => harga }=> \\
\text { minat beli => keputusan } \\
\text { pembelian }\end{array}$ & 4,679 & 0,000 & Siginifikan \\
\hline
\end{tabular}

Sumber : Pengolahan data Smart PLS 3.2

Berdasarkan tabel estimasi koefisien jalur dapat dijelaskan sebagai berikut :

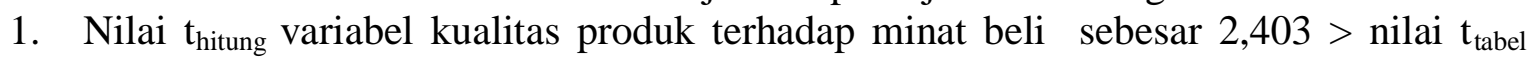
1,985, maka nilai estimasi koefesien signifikan.

2. Nilai $t_{\text {hitung }}$ variabel kualitas produk terhadap keputusan pembelian sebesar 3,808 > nilai $\mathrm{t}_{\text {tabel }} 1,985$, maka nilai estimasi koefesien signifikan.

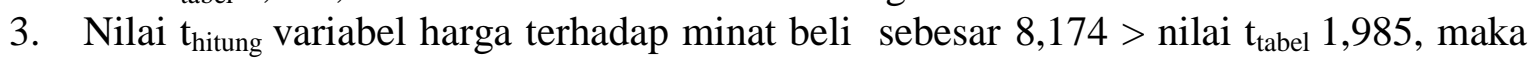
nilai estimasi koefesien signifikan.

4. Nilai $t_{\text {hitung }}$ variabel harga terhadap keputusan pembelian sebesar 1,654 $>$ nilai $t_{\text {tabel }}$ 1,985, maka nilai estimasi koefesien tidak signifikan.

5. Nilai $t_{\text {hitung }}$ variabel minat beli terhadap keputusan pembelian sebesar 6,096 > nilai $\mathrm{t}_{\text {tabel }} 1,985$, maka nilai estimasi koefesien signifikan.

6. Nilai $t_{\text {hitung }}$ variabel kualitas produk, harga, dan keputusan pembelian sebesar 1,662 > nilai $\mathrm{t}_{\text {tabel }} 1,985$, maka nilai estimasi koefesien tidak signifikan. 
7. Nilai $t_{\text {hitung }}$ variabel kualitas produk, harga, minat beli dan keputusan pembelian sebesar 4,679 > nilai $t_{\text {tabel }} 1,985$, maka nilai estimasi koefesien signifikan.

\section{Evaluasi goodness of fit} Outer model

\begin{tabular}{|l|c|c|c|c|}
\hline & $\begin{array}{c}\text { Cronbach's } \\
\text { Alpha }\end{array}$ & rho_A & $\begin{array}{c}\text { Composite } \\
\text { Reliability }\end{array}$ & $\begin{array}{c}\text { Average Varians } \\
\text { Extracted }(\boldsymbol{A V E})\end{array}$ \\
\hline $\begin{array}{l}\text { Kualitas } \\
\text { produk }\end{array}$ & 0,983 & 0,986 & 0,985 & 0,734 \\
\hline Harga & 0,948 & 0,968 & 0,959 & 0,675 \\
\hline Minat beli & 0,977 & 0,979 & 0,980 & 0,800 \\
\hline $\begin{array}{l}\text { Keputusan } \\
\text { pembelian }\end{array}$ & 0,974 & 0,984 & 0,979 & 0,761 \\
\hline
\end{tabular}

Sumber :Pengolahan data dengan Smart PLS 3.2

Berdasarkan tabel outer model, menunjukan bahwa semua variabel penelitian memiliki nilai composite reliability dan cronbach alpha diatas 0,70. Oleh karena itu indikator yang digunakan dalam variabel penelitian ini dikatakan reliabel. Sedangkan untuk menguji validitas menggunakan nilai average variance extracted dengan nilai batas diatas 0,5. Pada tabel outer model terlihat bahwa semua variabel memiliki nilai AVE diatas 0,50, hal ini dapat diartikan bahwa keseluruhan indikator dan varibael di nyatakan valid.

\section{Inner Model}

\begin{tabular}{|l|c|}
\multicolumn{1}{c}{} & Nilai $R$ - Square \\
\hline Minat beli & R Square \\
\hline Keputusan pembelian & 0,896 \\
\hline
\end{tabular}

Sumber :Pengolahan data dengan Smart PLS 3.2

Berdasarkan tabel R-Square diatas, dapat diketahui bahwa nilai R - Square untuk variabel minat beli adalah 0,896 atau 89,6\%. Kemudian untuk keputusan pembelian nilai $\mathrm{R}$ - Square yaitu sebesar 0,951 atau $95,1 \%$. Adapun hasil perhitungan nilai Q-Square adalah sebagai berikut :

$$
\begin{aligned}
\text { Q-Square } & =1-\left[\left(1-\mathrm{R}^{2} 1\right) \times\left(1-\mathrm{R}^{2} 2\right)\right] \\
& =1-[(1-0,896) \times(1-0,951) \\
& =1-(0,104 \times 0,049) \\
& =1-0,055 \\
& =0,945
\end{aligned}
$$

Hasil perhitungan diatas, diperoleh nilai Q-Square sebesar 0,945. Hal ini menunjukkan besarnya keragaman dari penelitian yang dapat dijelaskan oleh model penelitian adalah 94,5\%. Sedangkan sisanya sebesar 5,5 dijelaskan di faktor lain yang berada diluar model penelitian ini. Dengan demikian, dari hasil tersebut maka model penelitian ini dinyatakan telah memiliki goodness of fit yang baik. 


\section{Pengujian hipotesis}

T- statistic

\section{T-statistics}

\begin{tabular}{|l|c|c|c|c|}
\hline & $\begin{array}{c}\text { Koefisien } \\
\text { path }\end{array}$ & $\begin{array}{c}\text { T } \\
\text { Statistics }\end{array}$ & $\begin{array}{c}\text { P } \\
\text { Values }\end{array}$ & Hasil \\
\hline Kualitas produk => minat beli & 0,023 & 2,382 & 0,018 & Diterima \\
\hline $\begin{array}{l}\text { Kualitas produk => keputusan } \\
\text { pembelian }\end{array}$ & 0,282 & 3,505 & 0,000 & Diterima \\
\hline Harga => minat beli & 0,738 & 8,017 & 0,000 & Diterima \\
\hline Harga => keputusan pembelian & 0,196 & 1,535 & 0,125 & Ditolak \\
\hline $\begin{array}{l}\text { Minat beli => keputusan } \\
\text { pembelian }\end{array}$ & 0,522 & 5,671 & 0,000 & Diterima \\
\hline $\begin{array}{l}\text { Kualitas produk \& harga => } \\
\text { keputusan pembelian }\end{array}$ & 0,180 & 1,545 & 0,123 & Ditolak \\
\hline $\begin{array}{l}\text { Kualitas produk \& harga => } \\
\text { minat beli => keputusan } \\
\text { pembelian }\end{array}$ & 0,354 & 4,318 & 0,000 & Diterima \\
\hline
\end{tabular}

Sumber: Pengolahan data dengan Smart PLS 3.2

Berdasarkan tabel T- statistics diatas dapat diketahui bahwa :

1. Pengaruh kualitas terhadap minat beli dengan nilai $P$-Values sebesar $0,018<0,05$. Hal ini berarti $h_{0}$ ditolak $h_{a}$ diterima. Dengan demikian kualitas produk berpengaruh signifikan terhadap minat beli.

2. Pengaruh kualitas produk terhadap keputusan pembelian dengan nilai P-Values sebesar $0,000<0,05$. Hal ini berarti $h_{0}$ ditolak $h_{a}$ diterima. Dengan demikian kualitas produk berpengaruh signifikan terhadap keputusan pembelian.

3. Pengaruh harga terhadap minat beli dengan nilai $P$-Values sebesar $0,000<0,05$. Hal ini berarti $h_{0}$ ditolak $h_{a}$ diterima. Dengan demikian harga berpengaruh signifikan terhadap minat beli.

4. Pengaruh harga terhadap keputusan pembelian dengan nilai $P$-Values sebesar $0,125>$ 0,05 . Hal ini berarti $h_{0}$ diterima $h_{a}$ ditolak. Dengan demikian harga tidak berpengaruh signifikan terhadap keputusan pembelian.

5. Pengaruh minat beli terhadap keputusan pembelian dengan nilai P-Values sebesar $0,000<0,05$. Hal ini berarti $h_{0}$ ditolak $h_{a}$ diterima. Dengan demikian minat beli berpengaruh signifikan terhadap keputusan pembelian.

6. Pengaruh kualitas produk dan harga terhadap keputusan pembelian dengan nilai $P$ Values sebesar $0,123>0,05$. Hal ini berarti $\mathrm{h}_{0}$ diterima $\mathrm{h}_{\mathrm{a}}$ ditolak. Dengan demikian kualitas produk dan harga tidak berpengaruh signifikan terhadap keputusan pembelian.

7. Pengaruh kualitas produk dan harga terhadap keputusan pembelian melalui minat dengan nilai $P$-Values sebesar $0,000<0,05$. Hal ini berarti $h_{0}$ ditolak $h_{a}$ diterima. Dengan demikian kualitas produk dan harga terhadap keputusan pembelian berpengaruh signifikan melalui minat beli. 


\section{Path coefficients}

Koefesien path pengaruh langsung

\begin{tabular}{|l|c|c|c|}
\hline & $\begin{array}{c}\text { Koefesien } \\
\text { path }\end{array}$ & T Statistics & P Values \\
\hline Kualitas produk => minat beli & 0,023 & 2,382 & 0,018 \\
\hline $\begin{array}{l}\text { Kualitas produk => keputusan } \\
\text { pembelian }\end{array}$ & 0,282 & 3,505 & 0,000 \\
\hline Harga => minat beli & 0,738 & 8,017 & 0,000 \\
\hline Harga => keputusan pembelian & 0,196 & 1,535 & 0,125 \\
\hline Minat beli => keputusan pembelian & 0,522 & 5,671 & 0,000 \\
\hline
\end{tabular}

Sumber: Pengolahan data dengan Smart PLS 3.2

Berdasarkan tabel Koefesien path pengaruh langsung diatas dapat dirumuskan hal-hal sebagai berikut :

1. Pengaruh kualitas produk terhadap minat beli dengan koefesien path bernilai positif 0,023 , yang berarti bahwa setiap peningkatan kualitas produk akan meningkatkan minat beli sebesar $0,023 \times 100 \%=23 \%$.

2. Pengaruh kualitas produk terhadap keputusan pembelian dengan koefesien path bernilai positif 0,282 , yang berarti bahwa setiap peningkatan kualitas produk akan meningkatkan keputusan pembelian sebesar $0,282 \times 100 \%=28,2 \%$.

3. Pengaruh harga terhadap minat beli dengan koefesien path bernilai positif 0,738 , yang berarti bahwa setiap peningkatan harga akan meningkatkan minat beli sebesar $0,738 \mathrm{x}$ $100 \%=73,8 \%$.

4. Pengaruh harga terhadap keputusan pembelian dengan koefesien path bernilai positif 0,196, yang berarti bahwa setiap peningkatan harga akan meningkatkan keputusan pembelian sebesar $0,196 \times 100 \%=19,6 \%$.

5. Pengaruh minat beli terhadap keputusan pembelian dengan koefesien path bernilai positif 0,522 , yang berarti bahwa setiap peningkatan minat beli akan meningkatkan keputusan pembelian sebesar $0,522 \times 100 \%=52,2 \%$.

Pengujian pengaruh tidak langsung kualitas produk dan harga terhadap keputusan pembelian melalui minat beli dapat dilihat pada tabel berikut ini :

Koefesien path pengaruh tidak langsung

\begin{tabular}{|l|c|c|c|}
\hline & $\begin{array}{c}\text { Koefesien } \\
\text { path }\end{array}$ & T Statistics & P Values \\
\hline $\begin{array}{l}\text { Kualitas produk \& harga => keputusan } \\
\text { pembelian }\end{array}$ & 0,180 & 1,545 & 0,123 \\
\hline $\begin{array}{l}\text { Kualitas produk \& harga => minat beli } \\
\text { => keputusan pembelian }\end{array}$ & 0,354 & 4,318 & 0,000 \\
\hline
\end{tabular}

Sumber: Pengolahan data dengan Smart PLS 3.2

Berdasarkan tabel 5.38 dapat dirumuskan sebagai berikut :

1. Pengujian pengaruh kualitas produk dan harga secara tidak langsung terhadap keputusan pembelian dengan nilai koefesien path bernilai positif sebesar 0,180 . Hal 
ini berarti bahwa besarnya pengaruh tidak langsung kualitas produk dan harga terhadap keputusan pembelian sebesar $0,180 \times 100 \%=18 \%$.

2. Pengujian pengaruh kualitas produk dan harga secara tidak langsung terhadap keputusan pembelian melalui minat beli dengan nilai koefesien path bernilai positif sebesar 0,354. Hal ini berarti bahwa besarnya pengaruh tidak langsung kualitas produk dan harga terhadap keputusan pembelian melalui minat beli sebesar $0,354 \mathrm{x}$ $100 \%=35,4 \%$.

\section{Persamaan struktural}

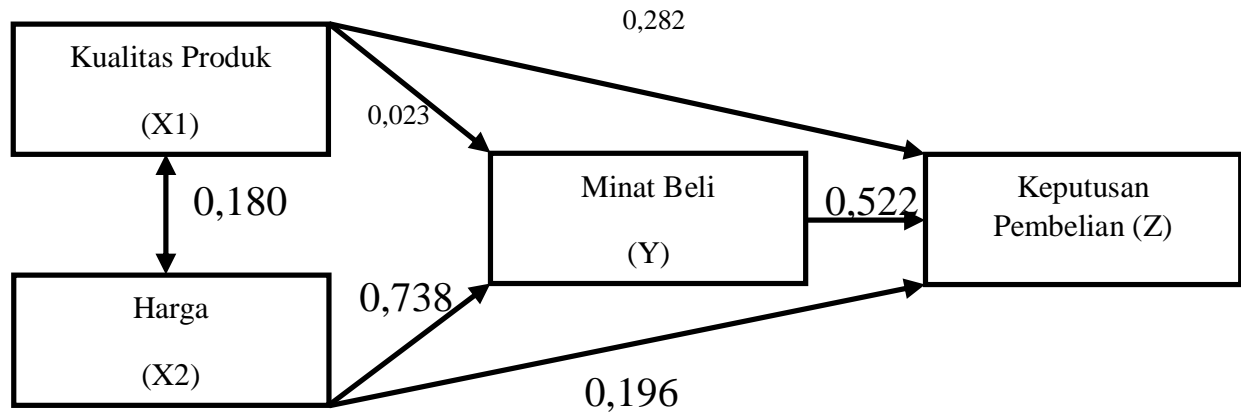

Persamaan hubungan struktural

Untuk persamaan hubungan struktural diagram jalur diatas dinyatakan dengan persamaan sebagai berikut :

1. Pengaruh $\mathrm{X}_{1}$ ke $\mathrm{Z}$ melalui $\mathrm{Y}$

a. Pengaruh langsung $X_{1}$

$\mathrm{Z} \Omega \mathrm{Y}=0,282.0,023.0,522$

b. Pengaruh tidak langsung $\mathrm{X}_{1}$

$\mathrm{Z} \Omega \mathrm{X}_{2} \Omega \mathrm{Y}=0,282.0,180.0,738.0,522$

2. Pengaruh $X_{2}$ ke $Z$ melalui $Y$

a. Pengaruh langsung $X_{2}$

$\mathrm{Z} \Omega \mathrm{Y}=0,196.0,783$

b. Pengaruh tidak langsung $\mathrm{X}_{2}$

$\mathrm{Z} \Omega \mathrm{X}_{1} \Omega \mathrm{Y}=0,196.0,180.0,023.0,522$

\section{Pembahasan}

\section{Pengaruh kualitas terhadap minat beli}

Hasil penelitian yang dilakukan berdasarkan kuesioner yang diisi oleh para responden menunjukan bahwa variabel kualitas produk memberikan pengaruh yang signifikan terhadap minat beli dengan nilai sebesar 0,018 . Hal ini menunjukkan bahwa sumbangan variabel kualitas produk terhadap minat beli sebesar $18 \%$.

\section{Pengaruh kualitas produk terhadap keputusan pembelian}

Hasil penelitian yang dilakukan berdasarkan kuesioner yang diisi oleh para responden menunjukan bahwa variabel kualitas produk memberikan pengaruh yang signifikan terhadap keputusan pembelian dengan nilai sebesar 0,282 . Hal ini menunjukkan bahwa sumbangan variabel kualitas produk terhadap keputusan pembelian sebesar $28,2 \%$.

\section{harga terhadap minat beli}

Hasil penelitian yang dilakukan berdasarkan kuesioner yang diisi oleh para responden menunjukan bahwa variabel harga memberikan pengaruh yang signifikan terhadap minat 
beli dengan nilai sebesar 0,738 . Hal ini menunjukkan bahwa sumbangan variabel harga terhadap minat beli sebesar $73,8 \%$.

\section{Pengaruh harga terhadap keputusan pembelian}

Hasil penelitian yang dilakukan berdasarkan kuesioner yang diisi oleh para responden menunjukan bahwa variabel harga tidak berpengaruh terhadap keputusan pembelian dengan nilai sebesar 0,196 .

\section{Pengaruh minat beli terhadap keputusan pembelian}

Hasil penelitian yang dilakukan berdasarkan kuesioner yang diisi oleh para responden menunjukan bahwa variabel minat beli memberikan pengaruh yang signifikan terhadap keputusan pembelian dengan nilai sebesar 0,522. Hal ini menunjukkan bahwa sumbangan variabel minat beli terhadap keputusan pembelian sebesar 52,2\%.

\section{Pengaruh kualitas produk dan harga terhadap keputusan pembelian}

Hasil penelitian yang dilakukan berdasarkan kuesioner yang diisi oleh para responden menunjukan bahwa variabel kualitas produk dan harga tidak berpengaruh terhadap keputusan pembelian dengan nilai sebesar 0,180 .

\section{Pengaruh kualitas produk dan harga terhadap keputusan pembelian melalui minat beli.}

Hasil penelitian yang dilakukan berdasarkan kuesioner yang diisi oleh para responden menunjukan bahwa variabel kualitas produk dan harga memberikan pengaruh terhadap keputusan pembelian melalui minat beli dengan nilai sebesar 0,354. Hal ini menunjukkan bahwa sumbangan variabel kualitas produk dan harga terhadap keputusan melalaui minat beli sebesar $35,4 \%$.

\section{SIMPULAN DAN SARAN}

\section{Simpulan}

1. Kualitas produk dikategorikan baik, harga tergolong tinggi, minat beli setuju, dan keputusan pembelian konsumen sangat setuju memiliki produk kosmetik JAFRA.

2. Variabel yang dominan berpengaruh terhadap keputusan pembelian yaitu variabel minat beli karena memiliki pengaruh secara langsung sebesar 52,2\% terhadap keputusan pembelian.

\section{Saran}

Semakin ketatnya persaingan bisnis kosmetik diharapkan pihak JAFRA untuk selalu mempertahankan konsumen dengan menjaga kualitas produk yang baik dan harga yang stabil dengan pesaing kosmetik sejenis sehingga konsumen dapat memenuhi harapannya untuk mendapatkan kualitas produk yang baik dan harga terjangkau sehingga konsumen beralih kepada produk sejenis lainnya.

Produsen kosmetik JAFRA sebaiknya meningkatkan elemen elemen aktivitas, minat dan opini yang dianggap baik pelaksanaannya oleh konsumen, sehingga faktor - faktor tersebut mampu mempengaruhi keputusan pembelian, maka dari itu akan muncul ide baru yang inovatif dan beragam sesuai dengan harapan konsumen.

Produsen diharapkan lebih melihat kembali target pasar dikalangan remaja dengan menawarkan harga produk yang terjangkau oleh remaja masa kini. 


\section{DAFTAR PUSTAKA}

Anwar, Iful, 2015, "Pengaruh Harga dan Kualitas Produk terhadap Keputusan Pembelian (Studi kasus di Showroom Maxim Housewares Grand City Mall Surabaya)". Jurnal Ilmu dan Riset Manajemen, Volume 4, Nomor 12, Desember 2015

Asshidin, Nor Hazlin Nor, Nurazariah Abidina dan Hafizzah Bashira Borhanb, 2016, "Perceived Quality And Emotional Value That Influence Consumer's Purchase Intention Towards American And Local Products". Procedia Economics and Finance, $35,639-643$

Dahmiri (2020). Influence of products and principles of sharia bank on customer decision with perception as intervening variable in Bank Jambi Syariah. Jurnal Perspektif Pembiayaan dan Pembangunan Daerah Vol. 7 No. 4, 393-404

Djatmiko, Tjahjono dan Rezza Pradana, 2015, "Brand Image And Product Price Its Impact For Samsung Smartphone Purchasing Decision”. Procedia - Social and Behavioral Sciences, 219, 221-227

Dinan, Fira, Azhad, M. naely, \& Fatimah, F. (2016). Analisis Faktor-Faktor Yang Memengaruhi Keputusan Pembelian Produk Kosmetik Oriflame Pada Mahasiswi Universitas Muhammadiyah Jember. Jurnal Manajemen Dan Bisnis Indonesia, 2(1), $1-15$.

Duli, N. (2019). Metode Penelitian Kuantitatif: Beberapa Konsep Untuk Penulisan Skripsi dan Analisis Data Dengan SPSS (Cetakn Per). DEEPUBLISH.

Erdalina, W. (2018). Pengaruh Kualitas Produk, Harga, dan Iklan Televisi terhadap Keputusan Pembelian Kosmetik Merek Citra Hand and Body Lotion di Pariaman. MENARA Ilmu, XII(9), 155-164.

Estu Mahanani. (2018). Pengaruh Citra Merek, Kualitas Produk, Harga Dan Gaya Hidup Terhadap Keputusan Pembelian Produk MataharimalL.COM. Kraith-Humaniora, 2(2), 53-61.

Firmansyah, M. A., \& Mahardika, B. W. (2018). Pengantar Manajemen (Ed 1). DEEPUBLISH.

Fitriana, Sudodo, Y., \& Hakim, L. (2019). Pengaruh Gaya Hidup, Harga, Dan Kualitas Produk Terhadap Keputusan Pembelian Kosmetik Oriflame. Jurnal Manajemen Dan Bisnis, 2(1).

Hilmawan, I. (2019). Pengaruh Kualitas Produk Dan Harga Terhadap Keputusan Pembelian Dengan Minat Beli Sebagai Variabel Intervening (Studi Pada Konsumen Sepeda Motor Vario Di Kota Serang). Jurnal Elektronik Rekaman (Riset Ekonomi Bidang Manajemen Dan Akuntansi) Sekolah Tinggi Ilmu Ekonomi Galileo, 3 (3), 154-166.

Iwan et all. (2019). Analisis Kualitas Produk Terhadap Minat Beli Dan Dampaknya Pada Keputusan Pembelian Produk Oriflame. Journal of Physics A: Mathematical and Theoretical, 3(3), 1-6.

Kotler, P., \& Keller, K. L. (2016). Manajemen Pemasaran (Ed 12). Indeks.

Narimawati, U., Sarwono, J., Affandy, A., \& Priadana, S. (2020). Ragam Analisis Dalam Metode Penelitian Untuk Penulisan Skripsi, Tesis, dan Disertasi (Ed 1). ANDI.

Novirina, I. S. \& Y. (2012). Analisis Pengaruh Citra Merek, Kualitas Produk, Dan Harga Terhadap Minat Beli Produk Oriflame (Studi Kasus Mahasiswi Fakultas Ekonomika dan Bisnis Jurusan Manajemen Universitas Diponegoro Semarang). Diponegoro Journal Of Management, 1, 1-17.

Oktavenia, K. A. R., \& Ardani, I. G. A. K. S. (2018). Pengaruh Kualitas Produk Terhadap Keputusan Pembelian Handphone Nokia Dengan Citra Merek Sebagai Pemediasi. E- 
Jurnal Manajemen Universitas Udayana, 8(3), 1374.

Pangastuti, J., Sudjiono, S., \& Prastiti, E. (2019). Pengaruh Kualitas Produk Dan Harga Terhadap Keputusan Pembelian Produk Kosmetik Wardah Pada Counter Wardah Di Borobudur Kediri. JIMEK: Jurnal Ilmiah Mahasiswa Ekonomi, 2(1), 69. https://doi.org/10.30737/jimek.v2i1.424

Ponirin, H. M. P. J. T. (2017). Pengaruh Kualitas Produk Dan Harga Terhadap Pembelian Kembali Produk Gosh Di Kota Palu Dengan Kepercayaan Merek Sebagai Variabel Antara (Studi Pada Mahasiswa Universitas Tadulako). 3(1), 57-68.

Puspita, C. mega, \& Budiatmo, A. (2012). Pengaruh Harga Dan Kualitas Produk Terhadap Keputusan Pembelian Dengan Minat Beli Sebagai Variabel Intervening (Studi Pada Rocket Chicken Wolter Monginsidi di Kota Semarang). III(29), 175-185.

Riyanto, S., \& Hatmawan, A. A. (2020). Metode Riset Penelitian Kuantitatif Penelitian Di Bidang Manajemen, Teknik, dan Pendidikan dan Eksperimen (Cetakan Pe). DEEPUBLISH.

Rizki, R. (2018). Pengaruh Kualitas Produk Dan Harga Terhadap Minat Beli Konsumen Produk Kosmetik Wardah. Jom Fisip, 5, 1-12.

Setiawan, R. (2017). Pengaruh Kualitas Produk dan Promosi Terhadap Keputusan Pembelian yang Berdampak Pada Loyalitas Pelanggan Pada Produk Hydro CocoPT Kalbe Farma. Jurnal Pendidikan, Hukum, Dan Bisnis, 2(1), 18-28.

Sunyoto, D. (2014). Dasar Dasar Manajemen Pemasaran (Cetakan 1). CAPS.

Tjiptono, F., \& Chandra, G. (2012). Pemasaran Strategik. ANDI.

Yulizar, R. intifada \& A. Z. (2019). Pengaruh Kualitas Produk Dan Harga Terhadap Minat Beli Di Shafira Cake \& Bakery. Ekono Insentif, 13(1), 41-55. 